\title{
FAKTOR PENDUKUNG IMPLEMETASI SIMDA DAN PENGARUHNYA TERHADAP KUALITAS LAPORAN KEUANGAN PADA SKPD KABUPATEN KULON PROGO
}

\author{
Mohammad Alfian \\ Universitas Sebelas Maret \\ alfian_fee20@yahoo.co.id
}

\begin{abstract}
This study determines the factors supporting the implementation of SIMDA (local government's financial management information system) on SKPDs (local government agencies) and the effect of SIMDA implementation toward financial statement quality. This research was based on the deficient SIMDA implementation, as demonstrated by inadequate accounting information quality. Inadequacy of accounting information quality was indicated by smaller number of SKPDs which obtain an unqualified opinion on their audit report. The population in this research is SKPDs in Kulon Progo, Yogyakarta. The samples were taken using judgmental purposive sampling method. The hypotheses were analyzed using structural equation model through SmartPLS. The results show that the quality of data input and the level of user knowledge about SIMDA positively affects the SIMDA implementation. Moreover, the top management support was not positively influence the SIMDA implementation. Furthermore, the research also found that the SIMDA implementation has positive influence toward the accounting information quality.
\end{abstract}

Keywords: SIMDA, local government agency, internal control, accounting information system

\section{PENDAHULUAN}

Rendahnya kualitas informasi akuntansi yang dihasilkan oleh pemerintah daerah dibuktikan dengan sedikitnya pemerintah daerah yang memperoleh opini wajar tanpa pengecualian (WTP) dari hasil audit atas Laporan Keuangan Pemerintah Daerah (LKPD) yang dilakukan oleh BPK (Badan Pemeriksa Keuangan). Hal tersebut dapat dilihat dari ikhtisar hasil pemeriksaan semester satu tahun 2012 yang dikeluarkan oleh BPK, yang memberikan informasi bahwa hanya 12 persen kabupaten dan 25 persen kota atau sebanyak 36 kabupaten dan 21 kota dari 313 kabupaten dan 85 kota yang memperoleh opini WTP. BPKP menyatakan bahwa tidak diperolehnya opini WTP oleh kabupaten dan kota disebabkan oleh beberapa faktor. Faktor tersebut antara lain adanya kelemahan sistem pengendalian internal, belum tertatanya barang milik negara/daerah, penyajian laporan keuangan yang belum sesuai dengan Standar Akuntansi Pemerintahan (SAP), kelemahan dalam 
sistem penyusunan laporan keuangan dan kurang memadainya kompetensi sumber daya manusia pengelola keuangan pada pemerintah daerah. LPKD merupakan gabungan dari laporan keuangan yang dihasilkan oleh SKPD-SKPD yang ada pada daerah tersebut. Dengan kata lain rendahnya kualitas LKPD merupakan cerminan rendahnya kualitas lapororan kuangan yang dihasilkan SKPD di daerah tersebut. Pemerintah beserta pihak-pihak terkait berusaha meningkatkan kualitas laporan keuangan yang dihasilkan. Hal ini tercermin dari dikeluarkannya Peraturan Pemerintah (PP) Nomor 71 tahun 2010 yang menggantikan PP Nomor 24 tahun 2005 dengan mengubah basis akuntansi menjadi basis akrual, guna meningkatkan kualitas informasi akuntansi yang terkandung dalam laporan keuangan.

Sistem informasi akuntansi merupakan alat yang digunakan oleh manajemen dalam organisasi untuk memberikan nilai tambah yang menghasilkan keunggulan kompetitif dan sebagai alat kontrol. Rostami dan Mongadam (2010) menyatakan bahwa teknologi informasi dapat digunakan sebagai pendukung yang sangat baik bagi organisasi dalam menjalankan strategi yang telah ditetapkan. Pada saat sistem informasi akuntansi (SIA) terintegrasi dengan teknologi informasi yang digunakan oleh organisasi tidak berjalan dengan baik, maka akan menghasilkan output informasi yang dapat melemahkan kinerja organisasi. Devi (2013) menyatakan bahwa keberhasilan sistem informasi suatu organisasi tergantung bagaimana sistem itu dijalankan, kemudahan sistem itu bagi para pemakainya dan pemanfaatan teknologi yang digunakan.

Penerapan sistem informasi akuntansi pada pemerintah daerah diatur dalam Peraturan Menteri Dalam Negeri Nomor 13 tahun 2006 tentang Pedoman Pengelolaan Keuangan Daerah. Peraturan tersebut mempunyai tujuan untuk memperbaiki informasi yang dihasilkan. Badan Pengawasan Keuangan dan Pembangunan (BPKP) memberikan respon positif dengan mengembangkan sebuah program aplikasi komputer yang diberi nama SIMDA (Sistem Informasi Manajemen Keuangan Daerah) yang mulai diperkenalkan pada tanggal 29 Agustus 2006. Program aplikasi ini dikembangkan oleh BPKP guna membantu pengelolaan keuangan daerah baik di tingkat Satuan Kerja Pengelola Keuangan Daerah (SKPKD, sebagai entitas pelaporan) maupun di tingkat Satuan Kerja Perangkat Daerah (SKPD, sebagai entitas akuntansi). Program aplikasi ini diharapkan bisa memberikan manfaat lebih kepada pemerintah daerah dalam melaksanakan pengelolaan keuangan. Namun berdasarkan pengamatan awal yang dilakukan oleh peneliti pada SKPD di lingkungan Pemerintah Kabupaten Kulon Progo, diperoleh gambaran kondisi pemanfaatan SIMDA yang lemah. SIMDA di Kabupaten Kulon Progo belum sepenuhnya digunakan secara optimal, sehingga penerapan SIMDA belum dapat membantu mencapai tujuan organisasi secara maksimal. SKPD juga dinilai kurang siap menerima dan mengaplikasikan software keuangan terintegrasi seperti SIMDA dalam menjalankan prosedur akuntansi. Belum ada kepastian tentang software yang dijadikan standar (default software) dalam prosedur akuntansi, yang menyebabkan 
masih beragamnya bentuk laporan keuangan yang dihasilkan oleh SKPD. Hal ini menyulitkan pengguna laporan keuangan dalam mengambil keputusan. Kemampuan penguasaan pengoperasian SIMDA belum merata di setiap SKPD. Aplikasi SIMDA menuntut penggunanya tidak hanya fasih dalam akuntansi tetapi juga dalam penggunaan komputer. Masih banyak ditemukan pegawai SKPD yang lebih memilih menggunakan kertas kerja manual atau dengan Microsoft Excell untuk menyelesaikan pekerjaannya yang dirasa lebih mudah daripada menggunakan SIMDA.

Penerapan SIMDA pada pemerintah daerah sebagai suatu organisasi sektor publik diharapkan dapat meningkatkan kualitas informasi akuntansi yang terkandung dalam laporan keuangan pemerintah daerah. Dengan meningkatnya kualitas laporan keuangan tersebut, diharapkan informasi akuntansi tersebut dapat digunakan sebagai bahan pengambilan keputusan dan sebagai bentuk pertanggungjawaban manajemen atas penggunaan sumber daya yang ada pada organisasi tersebut. Pertanyaan penelitian yang dikemukakan dalam riset ini adalah: (1) apakah tingkat pemahaman pengguna mengenai SIMDA berpengaruh positif terhadap implementasi SIMDA?; (2) apakah kualitas data input berpengaruh pada implementasi SIMDA?; (3) apakah dukungan manajemen puncak berpengaruh pada implementasi SIMDA? dan (4) apakah implementasi SIMDA berpengaruh positif terhadap kualitas laporan keuangan pada SKPD? Hasil penelitian ini diharapkan dapat menjadi bahan pertimbangan bagi pemerintah daerah dalam mengevaluasi pemanfaatan SIMDA, sehingga pada gilirannya dapat bermanfaat dalam mendorong peningkatan kualitas laporan keuangan. Hasil penelitian ini juga diharapkan dapat memberi kontribusi dalam memperkaya penelitian di ranah keuangan daerah.

\section{TELAAH PUSTAKA}

\section{Pengaruh Tingkat Pemahaman Pengguna terhadap Implementasi SIMDA}

Devi (2013) menyatakan bahwa kesuksesan penggunaan software tergantung pada teknologi itu sendiri dan tingkat keahlian individu yang mengoperasikannya. Kegiatan pelatihan juga dapat membangun rasa percaya diri user, sehingga mengantisipasi timbulnya kecemasan dan penolakan dari user terhadap sistem baru. Pemahaman pemakai tentang teknologi informasi menentukan keberhasilan suatu sistem informasi. Sebaliknya, ketidaktahuan atau kecemasan pemakai terhadap sistem yang baru dapat menyebabkan kegagalan dalam menggunakan teknologi informasi. Peningkatan pemahaman pemakai mengenai sistem informasi juga berpengaruh terhadap keberhasilan dalam memanfaatkan teknologi informasi (Sunarti dan Nur 1998). Hasil penelitian Hargo (2001) menyatakan bahwa tingkat pemahaman terhadap teknologi informasi secara signifikan berpengaruh terhadap implementasi teknologi informasi. Devi (2013) juga menyatakan bahwa tingkat 
pemahaman pengguna mempengaruhi keberhasilan implementasi sistem informasi akuntansi. Dengan demikian hipotesis pertama yang diajukan adalah sebagai berikut.

H1: Tingkat pemahaman berpengaruh positif terhadap implementasi SIMDA.

\section{Pengaruh Kualitas Data Input terhadap Implementasi SIMDA}

Seluruh proses menghasilkan data (mulai dari pengumpulan, penyimpanan serta penggunaan data) harus berjalan dengan baik agar data yang dihasilkan berkualitas baik pula. Lee dan Kuat dalam Al-Hiyari et al. (2013) menyatakan bahwa proses produksi data harus berjalan dengan baik agar mencapai hasil yang berkualitas. Sejalan dengan hal tersebut, Rahayu (2012) menyatakan bahwa data yang berkualitas dapat memengaruhi output dari SIA. Xu (2009) menyatakan bahwa kualitas output SIA bergantung dari input yang ada. Dengan demikian hipotesis yang diajukan adalah sebagai berikut.

H2: Kualitas data input berpengaruh positif terhadap implementasi SIMDA.

\section{Pengaruh Dukungan Manajemen Puncak terhadap Implementasi SIMDA}

Cooper (2006) menyatakan bahwa komitmen manajemen dipahami sebagai keterlibatan manajemen dalam mempertahankan perilaku untuk mencapai tujuan organisasi. Peningkatan komitmen manajemen terhadap perkembangan sistem akuntansi akan berdampak langsung terhadap kualitas implementasi SIA. Thong et al. (1996) menyatakan bahwa jika tingkat dukungan manajemen puncak rendah, maka manajemen puncak tidak mungkin terlibat dalam aspek pelaksanaan SIA. Penelitian tersebut menemukan bahwa komitmen manajemen dalam meningkatkan efektivitas sistem informasi dilakukan dengan menyediakan sumber daya yang dibutuhkan untuk proyek-proyek pengembangan SIA. Rahayu (2012) yang meneliti pengaruh komitmen manajemen terhadap kualitas data dan SIA, menemukan bahwa komitmen manajemen dan kualitas data bersama-sama memiliki efek yang memadai terhadap sistem informasi akuntansi. Dengan demikian hipotesis yang diajukan adalah sebagai berikut.

H3: Dukungan manajemen puncak berpengaruh positif terhadap implementasi SIMDA.

\section{Pengaruh Implementasi SIMDA terhadap Kualitas Laporan Keuangan}

Grande et al. (2011) mendefinisikan SIA sebagai alat yang dirancang untuk membantu dalam pengelolaan dan pengendalian topik yang terkait dengan bidang ekonomi serta keuangan perusahaan. Sejalan dengan hal tersebut, Salehi et al. (2010) menyatakan bahwa sistem informasi akuntansi meningkatkan kinerja individu dalam menghasilkan laporan keuangan yang berkualitas. Xu (2003) menyatakan bahwa kualitas informasi yang terkandung dalam laporan keuangan yang buruk dapat memiliki efek buruk pada pengambilan keputusan, misalnya kesalahan dalam informasi persediaan dapat menyebabkan pengambilan keputusan yang salah oleh 
para manajer. Kualitas informasi yang terkandung dalam laporan keuangan dapat dievaluasi dengan empat atribut yaitu akurasi, ketepatan waktu, kelengkapan dan konsistensi. Sejalan dengan Mc Leod et al. (2007), kualitas informasi diukur dengan empat dimensi yaitu relevansi, akurasi, ketepatan waktu dan kelengkapan. Dengan demikian hipotesis yang diajukan adalah sebagai berikut.

H4: Implementasi SIMDA berpengaruh positif terhadap kualitas laporan keuangan.

\section{METODA PENELITIAN}

Data dalam penelitian ini diperoleh dari sumber data primer dan sumber data sekunder. Data primer dalam penelitian ini berupa opini dan informasi dari responden yang diperoleh dengan memberikan kuesioner yang telah disusun kepada responden. Kuesioner diberikan secara langsung kepada responden, sehingga peneliti dapat menjelaskan mengenai penelitian yang akan dilakukan serta cara pengisian kuesioner.

Populasi yang diteliti dalam penelitian ini adalah SKPD di lingkungan pemerintah Kabupaten Kulon Progo yang menggunakan SIMDA dalam penyusunan laporan keuangan. Sampel pada penelitian ini diambil dengan metode purposive judgment sampling. Kriteria-kriteria dalam pemilihan sampel yaitu SKPD di lingkungan Pemerintah Kabupaten Kulon Progo, SKPD yang memiliki bagian keuangan atau akuntansi dan SKPD tersebut menggunakan SIMDA dalam penyusunan laporan keuangan.

Data dalam penelitian dikumpulkan dengan metoda survei, yaitu metode pengumpulan dan analisis data yang berupa opini dari subyek yang diteliti (responden) melalui tanya-jawab (Hartono 2013). Selanjutnya analisis data dalam penelitian ini menggunakan metoda partial least square (PLS). PLS dapat digunakan pada setiap jenis skala data (nominal, ordinal, interval dan rasio), serta syarat asumsi yang lebih fleksibel. PLS juga digunakan untuk mengukur hubungan setiap indikator dengan konstruknya. Selain itu, dalam PLS dapat dilakukan uji bootstrapping terhadap struktural model yang bersifat outer model dan inner model. Penelitian ini menggunakan indikator untuk mengukur setiap konstruknya dan juga menggunakan model yang bersifat struktural, maka diputuskan menggunakan PLS. Adapun teknik analisis data yang dilakukan adalah sebagai berikut.

a. Merancang model pengukuran (outer model).

Tahap ini digunakan untuk mengetahui validitas dan reliabilitas yang menghubungkan indikator dengan variabel latennya. Indikator dalam penelitian ini adalah reflektif karena indikator variabel laten memengaruhi indikatornya, sehingga digunakan tiga tahap pengukuran menurut Latan dan Ghozali (2012) yaitu sebagai berikut. 


\section{Discriminant validity}

Evaluasi yang dilakukan adalah melihat square root of average variance extracted $(A V E)$. Model pengukuran dinilai berdasarkan pengukuran cross loading dengan konstruk. Jika kolerasi konstruk dengan setiap indikatornya lebih besar daripada ukuran konstruk lainnya, maka konstruk laten memprediksi indikatornya lebih baik daripada konstruk lainnya. Jika nilai $\sqrt{A V E}$ lebih tinggi daripada nilai kolerasi di antara konstruk, maka discriminant validity yang baik tercapai. Menurut Latan dan Ghozali (2012), sangat direkomendasikan apabila $A V E$ lebih besar dari 0,5. Berikut adalah rumus untuk menghitung $A V E$.

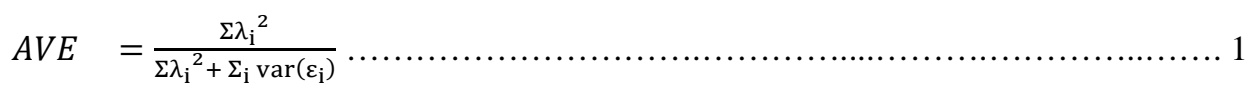

Keterangan:

$\lambda_{i} \quad=$ faktor loading (convergent validity)

$\operatorname{var}\left(\varepsilon_{\mathrm{i}}\right)=1-\lambda_{i}^{2}$

Fornnel dan Larcker (1981) dalam Latan dan Ghozali (2012) menyatakan bahwa pengukuran ini dapat digunakan untuk mengukur reliabilitas dan hasilnya lebih konservatif dibandingkan dengan nilai composite reliabity $(\rho c)$.

\section{Composite reliability}

Untuk menentukan composite reliability, apabila nilai composite reliability $\rho c>0,8$, maka dapat dikatakan bahwa konstruk memiliki reliabilitas yang tinggi atau reliable. Apabila nilai $\rho c>0,6$, maka dikatakan cukup reliable (Chin dalam Latan dan Ghozali 2012). Berikut rumus untuk menghitung composite reliability $(\rho c)$.

$\rho c=\frac{\left(\Sigma \lambda_{\mathrm{i}}\right)^{2}}{\left(\Sigma \lambda_{\mathrm{i}}\right)^{2}+\Sigma_{\mathrm{i}} \operatorname{var}\left(\varepsilon_{\mathrm{i}}\right)}$ 2

Berdasarkan hasil olah data yang dilakukan dengan bantuan software SmartPLS 2.0 M3 yang dapat dilihat pada Tabel 2, didapatkan bahwa nilai composite reliability untuk semua konstruk $>0,70$. Sehingga dapat disimpulkan bahwa semua indikator konstruk adalah reliable atau dengan kata lain memenuhi uji reliabilitas.

\section{Cronbach Alpha}

Dalam PLS, uji reliabilitas diperkuat dengan adanya cronbach alpha dimana konsistensi setiap jawaban diujikan. Cronbach alpha di katakan baik apabila $\alpha \geq 0,5$ dan dikatakan cukup apabila $\alpha \geq 0,3$.

b. Merancang model struktural (inner model).

Model struktural dievaluasi dengan menggunakan $R$-square $\left(R^{2}\right)$ untuk konstruk dependen, Stone-Geisser Q-square test untuk predictive relevance dan uji t serta signifikansi dari koefisien parameter jalur struktural. $R^{2}$ dapat digunakan untuk 
menilai pengaruh variabel laten independen terhadap variabel laten dependen apakah mempunyai pengaruh yang substantive.

c. Konstruksi diagram jalur.

d. Konversi diagram jalur ke sistem persamaan.

Dalam tahap ini dibuat persamaan untuk inner model dan outer model. Inner model menentukan spesifikasi hubungan antara konstruk laten satu dengan konstruk laten lainnya. Persamaan inner model adalah sebagai berikut.

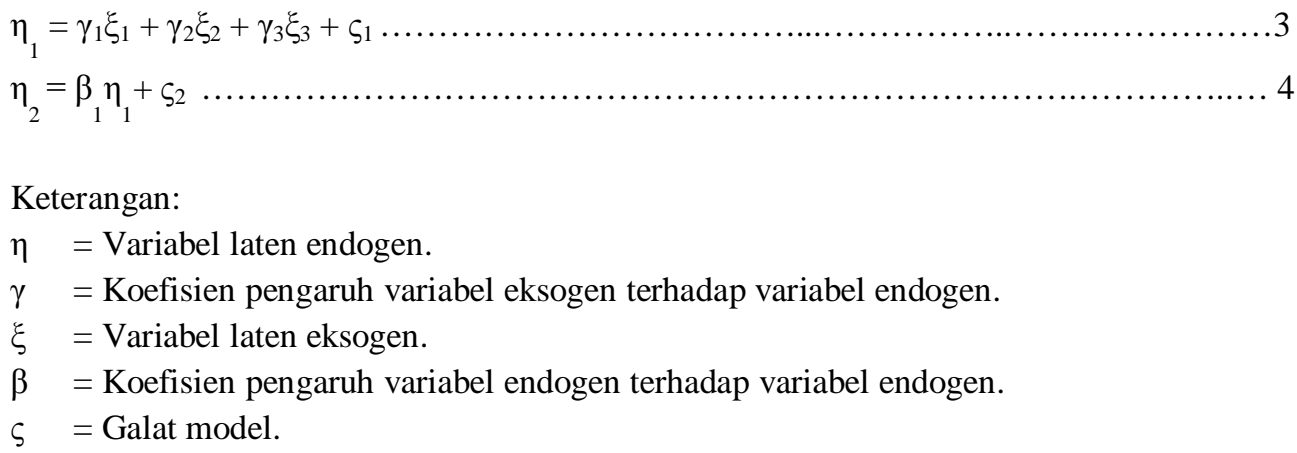

Selanjutnya outer model menentukan spesifikasi hubungan antara konstruk laten dan indikatornya. Persamaan outer model adalah sebagai berikut.

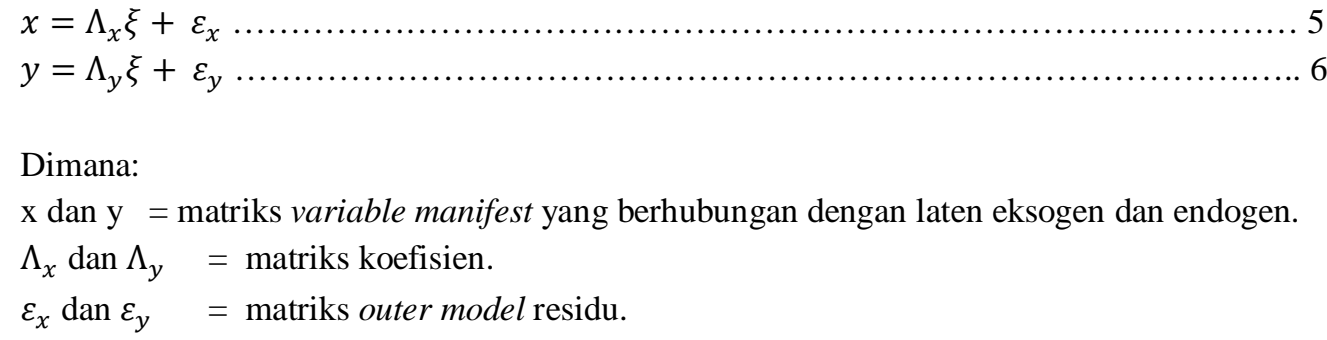

e. Uji hipotesis (resampling bootstraping).

Berdasarkan tujuan-tujuan penelitian, maka rancangan uji hipotesis yang dapat dibuat merupakan rancangan uji hipotesis dalam penelitian ini disajikan berdasarkan tujuan penelitian. Tingkat kepercayaan yang digunakan adalah 95 persen, sehingga tingkat presisi atau batas ketidakakuratan $(\alpha)$ sebesar 5 persen, dan menghasilkan nilai t-tabel sebesar 1.98 (Latan dan Ghozali 2012).

\section{HASIL PENELITIAN DAN PEMBAHASAN}

Kuesioner yang kembali adalah sebanyak 95 kuesioner dari 120 kuesioner yang disebarkan. Dari kuesioner yang telah kembali, sebanyak sembilan kuesioner tidak dapat digunakan karena kuesioner tersebut tidak diisi secara lengkap oleh responden. Kuesioner yang dapat diolah lebih lanjut berjumlah 86 buah, sehingga tingkat usable respon rate penelitian ini adalah sebesar 71,66 persen. Dari 86 responden, sebagian besar responden pria, yaitu sebanyak 46 responden atau 53,5 persen, dan sebanyak 40 responden atau sebesar 46,5 persen adalah wanita. Dari 86 responden, sebanyak 14 responden atau sebesar 16.3 persen adalah Sarjana S2, 45 
responden atau 52.3 persen adalah Sarjana S1, 14 responden atau 16.3 persen adalah Diploma (D3) dan 13 responden atau 15.1 persen adalah lulusan Sekolah Menengah Atas (SMA).

Berdasarkan hasil olah data yang dilakukan dengan bantuan software SmartPLS 2.0 M3 yang dapat dilihat pada Tabel 1, didapatkan hasil bahwa nilai AVE untuk semua konstruk $>0,50$. Hal ini berarti syarat validitas konvergen dapat terpenuhi. Selanjutnya diperoleh hasil bahwa nilai composite reliability untuk semua konstruk adalah $>0,70$. Hal ini berarti semua indikator konstruk adalah reliable atau dengan kata lain memenuhi uji reliabilitas. Nilai Cronbach alpha yang dihasilkan semua konstruk sangat baik yaitu sebesar $>0,7$, sehingga dapat disimpulkan bahwa semua indikator konstruk reflektif adalah reliable atau memenuhi uji reliabilitas. Namun demikian menurut Latan dan Ghozali (2012), dibandingkan menggunakan Cronbach alpha yang dihasilkan oleh PLS, disarankan untuk lebih menggunakan acuan pada composite reliability atau Dillion-Goldstein's.

Tabel 1

Rangkuman Hasil Olahan SmartPLS

\begin{tabular}{lcccc}
\hline \multicolumn{1}{c}{ Variabel } & AVE & $\begin{array}{c}\text { Composite } \\
\text { Reliability }\end{array}$ & $\begin{array}{c}\text { Cronbachs } \\
\text { Alpha }\end{array}$ & \multirow{2}{*}{$\boldsymbol{R}^{2}$} \\
\hline Dukungan manajemen puncak & 0,702657 & 0,876272 & 0,789965 & \\
Kualitas input data & 0,618860 & 0,827152 & 0,708122 & \\
Laporan keuangan & 0,665575 & 0,887439 & 0,827832 & 0,521133 \\
SIMDA & 0,627967 & 0,893643 & 0,850540 & 0,696276 \\
Tingkat pengetahuan pengguna & 0,656645 & 0,851395 & 0,738977 & \\
\hline Sumber: hasil olahan data dengan SmartPLS & & &
\end{tabular}

Sumber: hasil olahan data dengan SmartPLS

Dari Tabel 1 dapat dilihat juga bahwa nilai $R^{2}$ untuk variabel SIMDA menunjukan hasil 0,696276, yang berarti bahwa dukungan manajemen puncak, kualitas data input dan tingkat pengetahuan pengguna mengenai SIMDA memengaruhi implementasi SIMDA sebesar 69,6 persen. Hal tersebut menunjukan bahwa 30,4 persen faktor atau variabel lain yang mendukung implementasi SIMDA pada SKPD yang ada di Pemerintah Kabupaten Kulon Progo. Sedangkan nilai $R^{2}$ untuk variabel kualitas laporan keuangan sebesar 0,521133, yang menunjukan bahwa SIMDA memengaruhi kualitas laporan keuangan sebesar 52,1 persen, sehingga masih ada 47,9 persen variabel atau faktor lain yang memengaruhi kualitas laporan keuangan. 


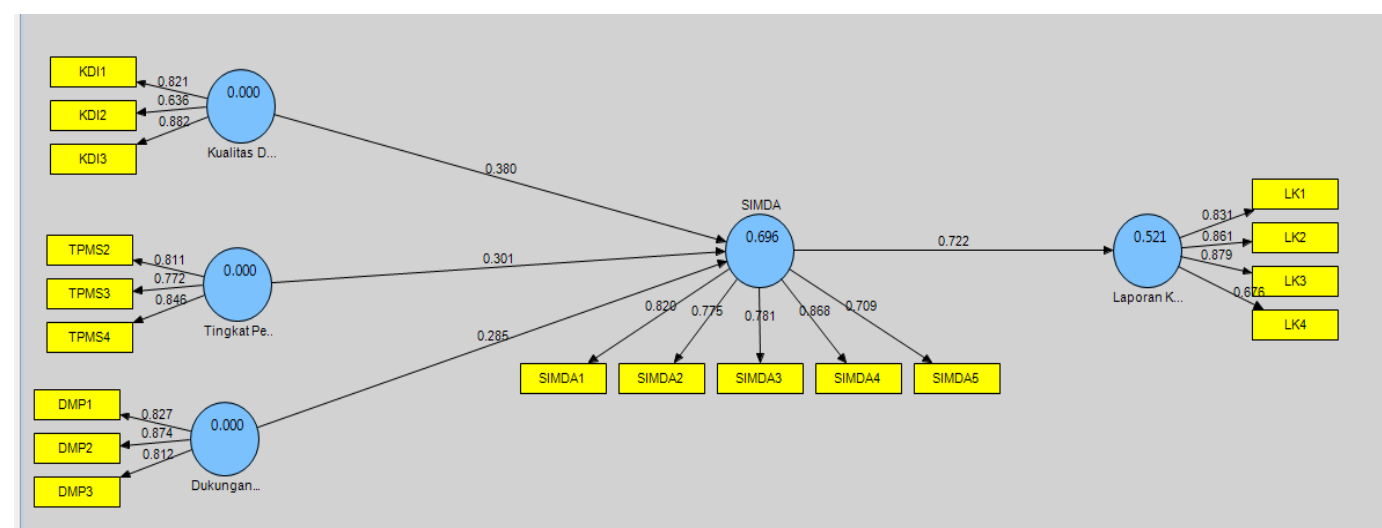

Sumber: SmartPLS 2.0

\section{Gambar 1}

\section{Konstruksi Diagram Jalur}

Berdasarkan pengolahan data menggunakan SmartPLS, diperoleh konstruksi diagram jalur seperti pada Gambar 1 di atas. Adapun koefisien masing-masing jalur disajikan terperinci pada Tabel 2 di bawah ini.

Tabel 2

Tabel Koefisien Jalur

\begin{tabular}{llllcc}
\hline \multicolumn{1}{c}{ Variabel } & $\begin{array}{c}\text { Original } \\
\text { Sample }\end{array}$ & Mean & Std. Dev. & $\begin{array}{c}\text { Std. } \\
\text { Error }\end{array}$ & t \\
\hline Tingkat pengetahuan pengguna $\rightarrow$ SIMDA & 0,0122 & 0,31141 & 0,15015 & 0,15015 & 2,00610 \\
Kualitas input data $\rightarrow$ SIMDA & 0,37958 & 0,39697 & 0,15272 & 0,15272 & 2,48548 \\
Dukungan manajemen puncak $\rightarrow$ SIMDA & 0,28528 & 0,27823 & 0,18493 & 0,18493 & 1,54263 \\
SIMDA $\rightarrow$ Laporan keuangan & 0,72190 & 0,73720 & 0,08552 & 0,08552 & 8,44133 \\
\hline
\end{tabular}

Sumber: hasil olahan data dengan SmartPLS

Berdasarkan path coefficients di atas dapat dilihat bahwa hanya dukungan manajemen puncak yang berpengaruh tidak signifikan terhadap SIMDA, sedangkan kualitas data input dan tingkat pengetahuan mengenai SIMDA berpengaruh positif terhadap implementasi SIMDA. Nilai t-statistics dari pengaruh tingkat pengetahuan pengguna mengenai SIMDA terhadap implementasi SIMDA adalah sebesar 2,00610 $>1,98$, hal tersebut berarti bahwa tingkat pengetahuan pengguna mengenai SIMDA berpengaruh positif terhadap implementasi SIMDA. Dengan demikian berarti hipotesis pertama didukung oleh temuan hasil penelitian. Hasil penelitian ini sejalan dengan Hargo (2001) dan Devi (2013). Nilai t-statistics dari pengaruh kualitas data input terhadap implementasi SIMDA adalah sebesar 2,48548>1,98, dimana hal tersebut berarti bahwa kualitas data input berpengaruh positif terhadap implementasi SIMDA. Dengan demikian berarti hipotesis ke dua didukung oleh temuan hasil penelitian. Hasil penelitian ini sejalan dengan Xu (2009), Rahayu (2012) danAlHiyari (2013). Nilai t-statistics dari pengaruh dukungan manajemen puncak terhadap implementasi SIMDA $1,54263<1,98$, hal tersebut berarti bahwa dukungan manajemen berpengaruh tidak signifikan terhadap implementasi SIMDA pada SKPD 
di lingkungan pemerintah Kabupaten Kulon Progo. Dengan demikian berarti hipotesis ke tiga tidak didukung oleh temuan hasil penelitian. Hasil penelitian ini tidak sejalan dengan Cooper (2006), Rahayu (2012) dan Al-Hiyari (2013). Nilai tstatistics dari pengaruh implementasi SIMDA terhadap kualitas laporan keuangan adalah 8,44133>1,98, dimana hal tersebut berarti bahwa implementasi SIMDA berpengaruh positif terhadap kualitas laporan keuangan atau LKPD yang dihasilkan oleh SKPD. Dengan demikian berarti hipotesis ke empat didukung oleh temuan hasil penelitian. Hasil penelitian ini sejalan dengan Rahayu (2012) danAl-Hiyari (2013).

Penelitian ini menemukan bahwa tidak digunakannya SIMDA oleh karyawan SKPD dalam penyusunan laporan keuangan pada pos-pos tertentu salah satunya disebabkan oleh keterbatasan kemampuan sumber daya manusia yang ada. Hal tersebut berpengaruh terhadap kualitas laporan keuangan yang dihasilkan dan tidak tercapainya tujuan dari implementasi SIMDA yang dicanangkan oleh BPKP sebagai salah satu faktor pendukung terciptanya Sistem Pengendalian Internal (SPI). Penelitian ini juga menemukan bahwa data input yang ada memiliki kriteria-kriteria tertentu sesuai yang disyaratkan oleh SIMDA. Aplikasi SIMDA sudah dirancang dengan menerapkan quality control data input yang baik, sehingga laporan keuangan yang dihasilkan memiliki kualitas yang baik. SKPD-SKPD yang ada di lingkungan pemerintah Kabupaten Kulon Progo memiliki masalah dengan kualitas data yang disyaratkan SIMDA, yang disebabkan oleh kurang baiknya pengelolaan data yang ada sehingga berpengaruh terhadap kualitas implementasi SIMDA. Penelitian ini juga menemukan bahwa banyak pegawai SKPD yang lebih memilih tidak menggunakan SIMDA untuk menyusun laporan keuangan pada pos-pos tertentu, melainkan memilih menggunakan Microsoft Office Excel atau alat bantu lainnya. Implementasi SIMDA pada SKPD-SKPD di lingkungan pemerintah Kabupaten Kulon Progo kurang mendapat respon positif atau dengan kata lain dukungan manajemen puncak tidak berpengaruh positif terhadap implementasi SIMDA. Kurangnya perhatian dari manajemen puncak dimungkinkan dapat sebagai penyebab rendahnya kualitas data input dan rendahnya pemahaman pengguna mengenai SIMDA. Berdasarkan penelitian ini dapat disimpulkan bahwa implementasi SIMDA perlu ditingkatkan kualitasnya karena dengan membaiknya kualitas SIMDA dapat meningkatkan kualitas laporan keuangan yang dihasilkan. Berdasarkan penelitian ini, perbaikan-perbaikan yang perlu dilakukan adalah peningkatan kualitas data input dengan meningkatkan kualitas sistem dokumentasi data. Setelah memperbaiki sistem dokumentasi data, perbaikan yang perlu dilakukan adalah dengan peningkatan pemahaman pengguna mengenai SIMDA. Namun dari kedua perbaikan tersebut yang terpenting adalah peningkatan dukungan atau peningkatan perhatian manajemen puncak terhadap implementasi SIMDA, sehingga dengan perhatian tersebut akan dapat mendorong perbaikan-perbaikan yang perlu dilakukan. 


\section{SIMPULAN}

Simpulan riset adalah, pertama, kualitas data input dan tingkat pemahaman pengguna mengenai SIMDA berpengaruh positif terhadap implementasi SIMDA pada pemerintah Kabupaten Kulon Progo. Kedua, dukungan manajemen puncak tidak berpengaruh positif terhadap implementasi SIMDA pada SKPD yang ada di Kabupaten Kulon Progo. Dengan kata lain H1 dan H2 berhasil didukung sedangkan H3 tidak berhasil didukung. Berdasarkan penelitian yang dilakukan juga diketahui bahwa implementasi SIMDA pada SKPD di lingkungan pemerintah Kabupaten Kulon Progo memiliki pengaruh positif terhadap kualitas laporan keuangan. Penelitian ini menyimpulkan bahwa implementasi SIMDA perlu ditingkatkan kualitasnya karena dengan membaiknya kualitas SIMDA dapat meningkatkan kualitas laporan keuangan yang dihasilkan. Perbaikan-perbaikan yang perlu dilakukan adalah peningkatan kualitas data input dan pemahaman pengguna mengenai SIMDA. Namun yang lebih penting adalah peningkatan dukungan atau perhatian manajemen puncak terhadap implementasi SIMDA.

Peneliti menyadari bahwa penelitian ini memiliki beberapa keterbatasan, antara lain sebagai berikut ini. Banyak faktor-faktor dalam implementasi sistem informasi lain yang dapat memengaruhi kualitas laporan keuangan, akan tetapi belum diteliti dalam penelitian ini, misalnya faktor demografi dan faktor lingkungan serta budaya organisasi. Penelitian selanjutnya diharapkan dapat memasukkan faktorfaktor tersebut untuk diteliti, misalnya umur, jenis kelamin, pengaruh lingkungan kerja, manfaat sistem informasi serta faktor-faktor lainnya. Peneliti juga menyarankan untuk tidak hanya mendasarkan pengukuran variabel penelitian pada persepsi responden saja. Pengumpulan data pada penelitian selanjutnya diharapkan tidak hanya terbatas pada penyebaran kuesioner saja, tetapi dapat pula dilakukan melalui wawancara. Kehadiran peneliti pada saat responden melakukan pengisian kuesioner sebaiknya juga dilakukan. Hal ini akan menghindarkan response bias, karena responden dapat menanyakan secara langsung mengenai pertanyaan yang kurang dipahami.

\section{DAFTAR PUSTAKA}

Al-Hiyari, A., M. H. H. Al-Mashregy, N. K. N. Mat, dan J. M. Alekam. 2013. Factors that affect accounting information system implementation and accounting information quality: a survey in University Utara Malaysia. American Journal of Economics. Vol.3 No.1: 27-31.

Cooper, D. 2006. The impact of management's commitment on employee behavior: a field study. American society of safely engineers.

Devi, V. F. P. 2013. Pengaruh implementasi sistem informasi akuntansi terhadap kinerja organisasi pemerintah daerah (penelitian pada SKPD di lingkungan 
pemerintah daerah Kabupaten Kulon Progo). Skripsi. Universitas Muhammadiyah Yogyakarta.

Endraswari, R. M. 2006. Faktor-faktor yang mempengaruhi aplikasi teknologi infoemasi dan pengaruhnya terhadap kinerja perusahaan (studi pada UKM kerajinan tangan Bantul, Yogyakarta). Tesis. Universitas Diponegoro.

Grande, E. U., R. P. Estébanez, dan C. M. Colomina. 2011. The impact of accounting information systems (AIS) on performance measures: empirical evidence in Spanish SMEs. The International Journal of Digital Accounting Research. Vol.11.

Hargo, U. 2001. Studi eksplorasi tentang penyebaran TI untuk usaha kecil dan menengah. Jurnal Ekonomi dan Bisnis Indonesia. Vol. 16 No. 2: 153-163.

Hartono, J. 2013. Metodologi Penelitian Bisnis Salah Kaprah dan PengalamanPengalaman, Edisi Kelima. Yogyakarta: BPFE. Fakultas Ekonomi dan Bisnis UGM.

Latan, H., dan I. Ghozali. 2012. Partial Least Squares Konsep, Teknik dan Aplikasi Menggunakan Program SmartPLS 2.0 M3. Semarang: Badan Penerbit Universitas Diponegoro.

Peraturan Menteri Dalam Negeri Nomor 13 Tahun 2006 Tentang Pedoman Pengelolaan Keuangan Daerah.

Peraturan Pemerintah Nomor 58 Tahun 2005 Tentang Pengelolaan Pemerintahan Daerah.

Peraturan Pemerintah Nomor 71 Tahun 2010 Tentang Standar Akuntansi Pemerintah.

Rahayu, S. K. 2012. The factors that support the implementation of accounting information system: a survey in Bandung and Jakarta's taxpayer offices. Journal of Global Management. Vol. 4 Issue 1.

Salehi, M., V. Rostami, dan A. Mogadam. 2010. Usefulness of accounting information system in emerging economy: empirical evidence of Iran. International Journal of Economics and Finance. Vol.2 No.2 (May).

Sunarti, S., dan I. Nur. 1998. Pengaruh dukungan manajemen puncak dan komunikasi pemakai-pengembang terhadap hubungan partisipasi dan kepuasan pemakai dalam pengembangan sistem informasi. Jurnal Riset Akuntansi Indonesia. Vol.1 No.2 (Juli): 193-207.

Thong, J. L., Y. C-Sing, dan K. S. Raman. 1996. Top management support, external expertise and information systems implementation in small businesses. Information Systems Research. Vol.7 No.2: 248-267.

Undang-Undang Nomor 17 Tahun 2003 Tentang Keuangan Negara. 
Undang-Undang Nomor 1 Tahun 2004 Tentang Perbendaharaan Negara.

$\mathrm{Xu}$, H. 2003. Critical success factors for accounting information systems data quality. Dissertation. University of Southern Queensland. 